\title{
İkinci Ürün Olarak Yetiştirilen Silajık Mısırda Ekim Şekilleri ile Farkı Bitki Sıklıklarının Verim ve Kalite Özellikleri Üzerine Etkisi
}

\author{
Gamze BAYRAM $^{1} \quad$ İlhan TURGUT ${ }^{1} \quad$ Emre ŞENYİĞITT ${ }^{1}$ \\ ${ }^{1}$ Uludağ Üniversitesi, Ziraat Fakültesi, Tarla Bitkileri Bölümü, BURSA \\ $\bowtie$ : gbayram@uludag.edu.tr
}

Geliş (Received): 02.11.2017

Kabul (Accepted): 15.12.2017

\begin{abstract}
ÖZET: Bu araştırma, Bursa koşullarında ikinci ürün olarak yetiştirilen mısırda uygun bitki sıklığı ve ekim şeklinin belirlenmesi ve bunların verim ve kalite üzerine olan etkilerini incelemek, bu konuda ileride yapılacak araştırmalara 1şık tutmak ve bölge çiftçilerine yardımcı olmak amacıyla yapılmışıı. Bu çalışmada bitki materyali olarak Bora çeşidi kullanılmıştır. Deneme, 2009-2010 yıllarında Uludağ Üniversitesi Ziraat Fakültesi Tarımsal Araştırma ve Uygulama Merkezi’nde yürütülmüsştür. Bölünmüş Parseller Deneme Desenine göre 3 tekrarlamalı olarak kurulmuştur. Denemede 3 farklı ekim şekli $(50 \mathrm{~cm}, 70 \mathrm{~cm}$ ve $25+45 \mathrm{~cm})$ ve 4 farklı bitki sıklığ $15500,7500,9500$ ve 11500 bitki da-1) kullanılmıştır. İki yıl süren bu araştırmada, bitki boyu, sap kalınlığı, yaprak oranı, yeşil ot verimi, kuru madde verimi, ham protein oranı belirlenmiştir.

Araştırmada, bitki boyu ekim şekillerinden etkilenmiş, bitki sıklığı arttıkça bitki boyunda artış saptanmıştır. Çift sıra ekim şeklinin daha kalın saplı bitki oluşturduğu belirlenmiştir. Artan bitki sıklıklarıyla birlikte sap kalınlığında azalma meydana gelmiştir. Çift sıra ekim yönteminde $(25+45 \mathrm{~cm})$ yaprak oranı, diğer ekim şekillerine göre daha yüksek bulunmuştur. En yüksek yaprak oranı, en yüksek bitki sıklığında elde edilmiş̧ir. Araştırma sonuçlarına göre, çift sıra ekiminde yeşil ot verimi önemli oranda artmıştır. Artan bitki sıklı̆̆ ve birim alandaki bitki sayısının da artmasıyla yeşil ot verimde artış olmuştur. Sonuç olarak, denemenin tarımsal ekolojik koşullarında ikinci ürün mısır üretiminde 11500 bitki da-1 yoğunluğu ve $25+45 \mathrm{~cm}$ ekim şeklinin daha iyi sonuç verdiği saptanmıştır.
\end{abstract}

Anahtar Kelimeler: Mısır, çift sıra ekim, bitki sıklığı, verim, kalite

\section{The Effect of Planting Patterns and Different Plant Density on Yield and Quality Characteristics of Silage Maize Grown as Second Crop}

\begin{abstract}
This research was carried out to determine the appropriate planting patterns and plant density in silage maize grown as a second crop in Bursa conditions and to examine their effects on yield and quality, to shed light on the future researches and to assist the farmers in the region. Bora variety was used as plant material in this study. The trial was carried out at the Agricultural Research and Application Center of the Agricultural Faculty of Uludağ University in 2009-2010. It was set up with 3 replications according to the split block trial design.Three different planting patterns $(50 \mathrm{~cm}, 70 \mathrm{~cm}$ and $25+45 \mathrm{~cm})$ and 4 different plant densities $(5500,7500,9500$ and 11500 plant da-1) were used in the experiment. In this two-year study, plant height, stem diameter, leaf ratio, forage yield, dry matter yield, crude protein content were determined.

In the study, the plant height was affected by the planting patterns, and the plant height was increased as the plant density increased.It has been determined that the twin-row planting produces plants with thicker stem. As the plant density increases, the stem diameter decreases. Leaf ratio in twin row planting patterns $(25+45 \mathrm{~cm})$ was found higher than other planting pattern. The highest leaf rate was obtained at the highest plant density. According to the results of the research, forage yield in twin-row planting patterns increased significantly. Increasing plant density and number of plants in the unit increased forage yield. As a result, it has been determined that 11500 plant da- 1 and $25+45 \mathrm{~cm}$ planting patterns for silage maize grown as second crop yielded better results under agro-ecological conditions of this experiment

Key Words: Maize, twin-row planting, plant population, yield, quality
\end{abstract}

\section{GİRIȘ}

Mısır güneş enerjisini en iyi şekilde kullanan ve birim alandan en fazla kuru madde üreten değişik iklim koşullarına adapte olmuş bir tahıldır (Shaw, 1988). Ülkemizde tahıllar grubu içerisinde buğday ve arpadan sonra en geniş ekim alanı ve üretime sahip olan mısır Türkiye tarımında önemli bir yere sahiptir. Üretilen mısır insan gıdası, hayvan yemi ve endüstride çok sayıda üretimin hammaddesini oluşturmaktadır. Tohumluğunun kolay temini, fazla miktarda yeşil aksam üretmesi, daha kaliteli ve lezzetli silaj üretebilmesi, herhangi bir katkı maddesine gerek duymadan silolanabilmesi ve tek biçim verdiği için işletmede iş planlamasını kolaylaştırması gibi nedenlerle mısır, diğer bitkilere nazaran ikinci ürün olarak tercih edilmektedir (Açıkgöz 2002). Yaz vejetasyon süresinin yeterli olduğu ve sulama olanaklarının bulunduğu yerlerde ikinci ürün üretimi kolaylıkla yapılabilmektedir.

İkinci ürün mısır tarımında üretimin arttırılması ve ürünün kalitesinin yükseltilmesi, kültürel işlemlerin zamanında yapılması ve en önemlisi de dekardaki bitki sayısına bağlıdır. Tarlada bitki sıklığı değişikliği, genellikle sıra arası ve sıra üzeri mesafeler değiştirilerek yapılmaktadır. Ancak son yıllarda, çift sıra ekim 
yöntemi uygulamasının da verimi etkilediği görülmüştür (Turgut ve ark. 2005; Yılmaz ve ark. 2008). Gereğinden fazla sık ekim koçan bağlamayan bitki sayısını arttırmaktadır. Çok seyrek ekim ise birim alandan alınan ürün miktarının azalmasına sebep olmaktadır. Çift sıra ekimde bitkilere daha fazla yaşam alanı düşmekte ve daha fazla 1şıklanma alanı sağlamaktadır (McGrath, 2005; Olson ve ark. 1988 ). Gözübenli ve ark. (2004), yaptıkları araştırmada çift sıra ekimin tek sıra ekime \% 4 verim farkı verdiğini belirtmiştir. Buehring ve ark. (2003) çift sıra mısır ekiminde, farklı çevre şartlarında farklı genotiplerin verim potansiyellerinin araştırılmasını rapor etmektedir. Bu noktadan hareketle, bu çalışma Bursa koşullarında ikinci ürün olarak yetiştirilen silajlık mısırda uygun bitki sıklığı ve ekim şeklinin belirlenmesi ve bunların verim ve kalite üzerine olan etkilerini incelemek, bu konuda ileride yapılacak araştırmalara 1şık tutmak ve bölge çiftçilerine yardımcı olmak amacıyla yapılmıştır.

\section{MATERYAL ve METOT}

Araştırma, iki yıl süre ile Uludağ Üniversitesi Ziraat Fakültesi Tarımsal Araştırma ve Uygulama Merkezi deneme alanlarında, bölünmüş parseller deneme desenine göre 3 tekrarlamalı olarak yürütülmüştür. Denemede 4 farklı bitki sıklığ $15500,7500,9500$, ve 11500 bitki da $\left.^{-1}\right)$ ve 3 farklı ekim şekli $(50 \mathrm{~cm}, 70 \mathrm{~cm}$, $25+45 \mathrm{~cm})$ kullanılmıştır. Ekim şekli ana parsellere ve bitki sıklıkları ise alt parsellere yerleştirilmiştir. Bir alt parsel 3.5 x $5=17.5 \mathrm{~m}^{2}$ 'lik bir alandan oluşmuştur. $\mathrm{Bu}$ çalışmada bitki materyali olarak özel sektörden temin edilen erkenci grupta yer alan Bora çeşidi (FAO 500) kullanılmıştır.
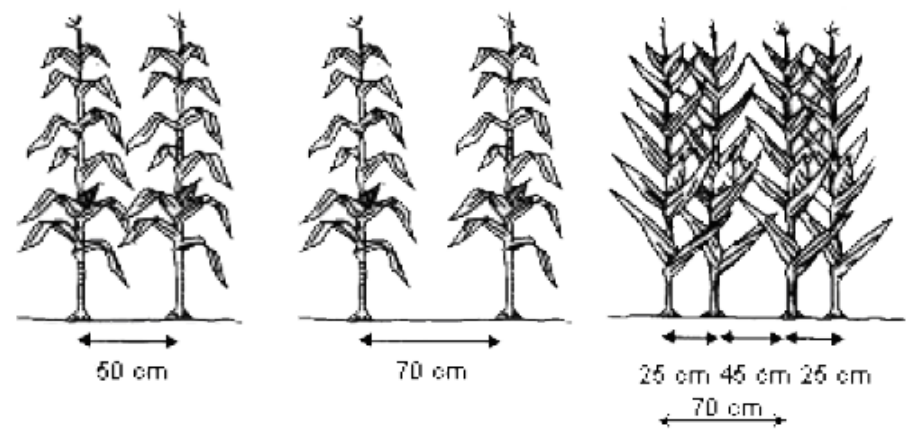

Şekil.1 Araştırmada Kullanılan Ekim Şekilleri

Araştırmanın yürütüldüğü yıllar ve uzun yıllara ait iklim verileri Çizelge1 'de özetlenmiştir. Çizelge 1'de görüldüğü gibi, uzun yıllar sıcaklık değeri $21.0^{\circ} \mathrm{C}$ 'dir. Çalışmanın yürütüldüğü 2009 yılı 4 aylık ortalama sıcaklık $\left(22.4{ }^{\circ} \mathrm{C}\right)$ değeri, uzun yıllar değerinden biraz yüksek, 2010 yılına ait değer $\left(21.8{ }^{\circ} \mathrm{C}\right)$ ise hemen hemen aynı gerçekleşmiştir. Toplam yağış miktarları incelendiğinde, 2009 yllında $109.7 \mathrm{~mm}, 2010$ yılında ise
279.7 m'dir. Çalışmanın ilk yılına ait toplam yağış miktarı uzun yıllara ait değerin biraz altında kalırken, 2010 yılında çok fazla yağış düştüğü görülmüştür (Çizelge 1).

Deneme alanı toprakları killi bünyeli, hafif alkali reaksiyonda, fosfor ve potasyumca zengin, organik maddece fakir ve orta derecede kireçli olup, tuzluluk sorunu bulunmamaktadir.

Çizelge 1. Araştırmanın Yürütüldüğü Yıllar ile Uzun Yıllara (UYO) Ait Ortalama Sıcaklık $\left({ }^{\circ} \mathrm{C}\right)$ ve Toplam Yağış Değerleri (mm)

\begin{tabular}{lcccccc}
\hline \multirow{2}{*}{ Aylar } & \multicolumn{2}{c}{ Ortalama Sıcaklık $\left({ }^{\circ} \mathbf{C}\right)$} & \multicolumn{3}{c}{ Toplam Yağış Değerleri (mm) } \\
\cline { 2 - 7 } & $\mathbf{2 0 0 9}$ & $\mathbf{2 0 1 0}$ & UYO & $\mathbf{2 0 0 9}$ & $\mathbf{2 0 1 0}$ & UYO \\
\hline Temmuz & 25.6 & 25.9 & 24.5 & 4.4 & 25 & 25.1 \\
\hline Ăgustos & 27.9 & 24.5 & 24.1 & 0 & 5.2 & 17.7 \\
\hline Eylül & 21.4 & 19.8 & 20.1 & 67.4 & 52.9 & 39.7 \\
\hline Ekim & 14.7 & 17.1 & 15.6 & 37.9 & 196.6 & 56.2 \\
\hline Top/Ort. & 22.4 & 21.8 & 21.0 & 109.7 & 279.7 & 138.7 \\
\hline
\end{tabular}

Deneme alanında toprak hazırlığı için sonbaharda pullukla derin sürüm yapılmış ve ilkbahara kadar boş bırakılmıştır. Daha sonra ilkbaharda yüzlek bir sürüm yapılmasıyla birlikte toprak frezesi geçirildikten sonra parselizasyon yapılmıştır. Farklı bitki sıklıkları ayarlamak için ölçüm cetvelleri yapılmış ve her ocağa 2 tohum düşecek şekilde ekim her iki yılda da Temmuz ayının ilk haftası elle yapılmıştır. Her iki yılda da, ekimle birlikte temel gübre olarak, $10 \mathrm{~kg} / \mathrm{da} \mathrm{N}, 10 \mathrm{~kg} / \mathrm{da}$
$\mathrm{P}_{2} \mathrm{O}_{5}$ ve $10 \mathrm{~kg} / \mathrm{da} \mathrm{K}_{2} \mathrm{O}$ gelecek şekilde kompoze (15-1515) gübresi verilmiştir. Bitkiler $50-60 \mathrm{~cm}$ boylandığında, azotun ikinci yarısı $10 \mathrm{~kg} / \mathrm{da}$ dozunda bitki sıralarının yanına elle serpilerek uygulanmıştır (Geren, 2000). Çıkıştan sonra misırlarda seyreltme yapılarak istenilen bitki sıklıkları elde edilmiştir. Yetiştirme süresi boyunca, toprağın nem durumu ve bitkilerin morfolojik görünümlerine göre bitkilerin su ihtiyacı karşılanmıştır. Yabancı otlara karşı mekanik 
mücadele yapılmıştır. Mısır koçanındaki tanelerde süt çizgisi tanenin 2/3'üne ulaştı̆̆ 1 dönemde (İptaş, 1993; Geren, 2000), kenardaki iki sıra ile parsel başlarından $50 \mathrm{~cm}$ 'lik kısımlar kenar tesirleri bırakıldıktan sonra Ekim ayının ilk haftası hasat yapılmıştır. Araştırmada bitki boyu $(\mathrm{cm})$, sap kalınlığ $1(\mathrm{~mm})$, yaprak oranı $(\%)$, yeşil ot verimi $\left(\mathrm{kg} \mathrm{da}^{-1}\right)$, kuru madde verimi $\left(\mathrm{kg} \mathrm{da}^{-1}\right)$ ve ham protein oranı $(\%)$ incelenmiştir. Çalışma süresince elde edilen veriler bölünmüş parseller deneme desenine göre varyans analizine tabi tutulmuştur. Bütün hesaplamalar bilgisayarda JUMP paket programlarından faydalanılarak yapılmıştır.

\section{BULGULAR ve TARTIŞMA}

İki yıllık verilere uygulanan varyans analiz sonuçlarına göre, bitki boyu, yaprak oranı açısından ekim şekilleri arasındaki farklılık \%5, diğer özellikler açısından ise $\% 1$ olasılık düzeyinde önemli çıkmıştır. İncelenen bütün özellikler bakımından bitki sıklıkları arasındaki farklılık \%1 olasılık düzeyinde önemli olmuştur. Ekim şekli x bitki sıklığı interaksiyonu incelendiğinde ise bitki boyu açısından $\% 5$, kuru madde verimi açısından $\% 1$ olasılık düzeyinde önemli çıkarken, diğer özelliklerde önemsiz bulunmuştur. Yıllar arasındaki farklılıklara bakıldığında ise, bitki boyu, sap kalınlığı ve ham protein oranı üzerinde y1lların etkisinin \%1 olasılık düzeyinde, yaprak oran1, yeşil ot verimi ve kuru madde verimi üzerinde ise $\% 5$ olasılık düzeyinde önemli olduğu belirlenmiştir (Çizelge 2).

Bitki boyu mısırda vejetatif gelişmenin bir göstergesi olmakla birlikte verim üzerine etkili özelliklerden biridir. İki yıllık ortalama verilere göre, 50 cm'de bitki boyu $242.8 \mathrm{~cm}, 70 \mathrm{~cm}$ 'de $244.8 \mathrm{~cm}$ iken $25+45 \mathrm{~cm}$ 'de $245.6 \mathrm{~cm}$ olarak belirlenmiştir (Çizelge 2). Mısır bitkisi ile yürütülen araştırmalarda, ekim sıklığı artıkça genellikle bitki boyunun da arttığı saptanmıştır (Dostalek ve Hruska 1985). Bitki sıklığının artması ile boğum arası uzunluğu ve dolayısıyla bitki boyu artmakta fakat sap kalınlığı azalmaktadır (Kolcar ve Videnovic 1985). Bitki sıklıklarının bitki boyuna etkisi önemli olmuştur. 11500 bitki da ${ }^{-1}$ sıklığına kadar bitki boyu artmış ve $253.2 \mathrm{~cm}$ ile en yüksek değer elde edilmiş, en kısa boy ise 5500 bitki da ${ }^{-1}$ sıklığında saptanmıştır. Farklı koşullarda yapılan benzer çalışmalarda bitki sıklığı arttıkça bitki boyunda artış saptanmıştır (Gözübenli ve ark. 2004; Yılmaz ve ark. 2008). Ekim şekli x Bitki sıklığı interaksiyonu incelendiğinde; bu iki faktörün bir araya gelmesiyle ortaya çıkan sonuca göre en yüksek bitki boyu $25+45$ ekim şeklinde 11500 bitki $\mathrm{da}^{-1}$ parsellerinde tespit edilmiştir.

Araştırmada elde edilen verilere göre, ekim şeklinin sap kalınlığına etkisi istatistiki olarak önemli bulunmuştur. En fazla sap kalınlığı değeri 25+45 ekim şeklinde $23.2 \mathrm{~mm}$ olarak belirlenmiştir. Gözübenli ve ark.(2004), Hatay koşullarında mısırda sap kalınlığının ikiz sıra ekim şeklinde tek sıra ekim şekline göre farklı olduğunu, Turgut ve ark.(2005) alternatif sıra aralığının daha kalın sap oluşturduğunu saptamışlardır. Sap kalınlığı bitki sıklıklarından önemli derecede etkilenmiştir. Artan bitki sıklıkları bitkiler arasında 1şığa rekabet oluşmuş ve beraberinde bitki boyunda uzama meydana gelirken, sap kalınlığının azalmasına neden olmuştur. Araştırıcıların elde ettikleri bulgularımızı destekler niteliktedir ( Şener ve ark. 2004; Turgut ve ark. 2005; Saruhan ve Şireli 2005).

Genel olarak misır bitkisiyle yapılan silajlarda bitkide koçan ve yaprak oranının sap oranına göre yüksek olması arzulanır. Bunun nedeni bitkide koçan ve yaprakların saplara göre daha besleyici olmasıdır (Saruhan ve Şireli 2005). Araştırmada ele alınan ekim şekilleri yaprak oranına etkileri istatistiki olarak önemli olmuş, $25+45 \mathrm{~cm}$ ekim şeklinde yaprak oranı $70 \mathrm{~cm}$ ve $50 \mathrm{~cm}$ ekim şekline göre daha yüksek bulunmuştur. Yaprak oranı üzerine bitki sıklıklarının etkileri istatistiki olarak önemli olmuş, en yüksek yaprak oranı 11500 bitki da ${ }^{-1}$ sıklığında \%30.1 olarak belirlenmiştir. Yılmaz ve ark. (2008), misırda en yüksek yaprak oranının en yüksek bitki sıklığı olan 12000 bitki da ${ }^{-1}$, dan \%17 değeriyle elde edildiğini bildirmişlerdir.

Araştırmada yeşil ot verimine ekim şekilleri önemli etkide bulunmuştur. $25+45 \mathrm{~cm}$ ekim şeklinde yeşil ot veriminde yüksek değerler belirlenmiştir. Dünyada ve ülkemizde son yıllarda yapılan çalışmaların büyük bölümü çift sıra ekim şeklinin kullanılması gerektiğini ortaya koymuştur. Turgut ve ark. (2005), 25+45 cm ekim şeklinin yüksek yeşil ot verimi için $70 \mathrm{~cm}$ ekim şeklinden daha iyi olduğunu vurgulamışlardır. Yılmaz ve ark. (2008), yaptıkları çalışmalarında $25+45 \mathrm{~cm}$ ekim şeklinin, $70 \mathrm{~cm}$ ve $50 \mathrm{~cm}$ 'ye göre sirasıyla $\% 16$ ve $\% 7.9$ daha fazla yeşil ot verimine sahip olduğunu belirtmişlerdir. Artan bitki sıklığı ile birim alandaki bitki sayısının da artmasıyla verimde artış olmaktadır. Ancak birim alanda çok fazla bitki bulunması koçansız bitki sayısını artıracak ve bu nedenle silaj kalitesinin düşmesine neden olacaktır (Saruhan ve Şireli 2005). Yapılan çalışmada, bitki sıklıklarının yeşil ot verimine etkisi önemli bulunmuştur. Bitki sıklığı arttıkça yeşil ot verimi de artmıştır. Farklı koşullarda yapılan benzer çalışmalarda aynı sonuçlar bildirilmiştir (Kızılşı̧̇şek ve ark. 2005; Turgut ve ark. 2005; Y1lmaz ark. 2008).

Bitkilerde vejetasyon dönemi ilerledikçe kuru madde verimi de artmaktadır. Mısırın yem değeri bitkinin olgunluk durumuna, koçan oranına, kuru madde içeriğine göre değişim göstermektedir (Heimbeck ve ark. 1988). Araştırmada kuru madde verimine ekim şekillerinin etkileri istatistiki olarak önemli bulunmuştur. İki yılın sonuçlarına göre, $25+45 \mathrm{~cm}$ ekim şekli kuru ot veriminde $70 \mathrm{~cm}$ ekim şekline göre $\% 17.5$, $50 \mathrm{~cm}$ ekim şekline göre ise \%25.7 üstünlük sağlamıştır. Benzer konularda çalışan Cox ve Cherney (2001) misirda $38 \mathrm{~cm}$ sira aralığındaki kuru madde veriminin $76 \mathrm{~cm}$ sıra aralığındaki kuru madde veriminden $\% 7.5$ daha fazla olduğunu, Turgut ve ark. (2005) 40+25 cm ekim şeklinin $65 \mathrm{~cm}$ ekim şekline göre daha yüksek kuru madde verdiğini tespit etmişlerdir. Bitki sıklıklarının kuru madde verimine etkisi önemli olmuş, bitki sıklığı arttıkça kuru madde verimi artmıştır. En yüksek kuru madde verimi (2221.2 $\left.\mathrm{kg} \mathrm{da}^{-1}\right) 11500$ bitki $\mathrm{da}^{-1}$ bitki sıklığındaki parsellerden elde edilmiştir. 
Cusicanqui ve Lauer , (1999) bitki sıklığı arttıkça kuru madde veriminde arttığını, Yllmaz ve ark. (2007) ise mısırda 11400 bitki da $^{-1}$ bitki sıklığında en yüksek kuru madde verimi elde ettiklerini vurgulamışlardır. Araştırıcıların bulguları sonuçlarımızı destekler niteliktedir.

Çizelge 2. Farklı Ekim Şekilleri ve Bitki Sıklıklarında İkinci Ürün Olarak Yetiştirilen Silajlık Mısırda İki Yıllık Ortalamalara Ait Bitki Boyu, Sap Kalınlı̆̆ı, Yaprak Oranı, Yeşil Ot Verimi, Kuru Madde Verimi ve Ham Protein Oranı Değerleri

\begin{tabular}{|c|c|c|c|c|c|c|}
\hline & $\begin{array}{l}\text { Bitki Boyu } \\
\quad(\mathbf{c m})\end{array}$ & $\underset{\substack{\text { Sap } \\
\text { Kalınlığı } \\
(\mathbf{m m})}}{ }$ & $\begin{array}{c}\text { Yaprak } \\
\text { Oranı } \\
(\%)\end{array}$ & $\begin{array}{c}\text { Yeşil Ot } \\
\text { Verimi } \\
\left(\text { kg.dat }^{-1}\right)\end{array}$ & $\begin{array}{c}\text { Kuru Madde } \\
\text { Verimi } \\
\left(\mathbf{k g ~ d a}^{-1}\right)\end{array}$ & $\begin{array}{c}\text { Ham } \\
\text { Protein } \\
\text { Oranı } \\
(\%) \\
\end{array}$ \\
\hline \multicolumn{7}{|l|}{ Ekim Şekli (cm) } \\
\hline 50 & $242.8 \mathrm{~b}$ & $20.4 \mathrm{~b}$ & $24.4 \mathrm{~b}$ & $4800.2 \mathrm{c}$ & $1646.6 \mathrm{c}$ & $7.4 \mathrm{c}$ \\
\hline 70 & $244.8 \mathrm{ab}$ & $21.0 \mathrm{~b}$ & $25.3 \mathrm{~b}$ & $5017.3 \mathrm{~b}$ & $1767.4 \mathrm{~b}$ & $7.8 \mathrm{~b}$ \\
\hline $25+45$ & $245.6 \mathrm{a}$ & $23.2 \mathrm{a}$ & $27.1 \mathrm{a}$ & 5439.2 a & $2095.5 \mathrm{a}$ & $8.5 \mathrm{a}$ \\
\hline \multicolumn{7}{|c|}{ Bitki Sıklı̆̆ (bitki da ${ }^{-1}$ ) } \\
\hline 5500 & $233.7 \mathrm{~d}$ & $24.1 \mathrm{a}$ & $19.6 \mathrm{~d}$ & $4456.1 \mathrm{~d}$ & $1397.2 \mathrm{~d}$ & $6.8 \mathrm{~d}$ \\
\hline 7500 & $241.5 \mathrm{c}$ & $22.5 \mathrm{~b}$ & $25.4 \mathrm{c}$ & $4852.5 \mathrm{c}$ & $1697.8 \mathrm{c}$ & $7.7 \mathrm{c}$ \\
\hline 9500 & $249.2 \mathrm{~b}$ & $20.6 \mathrm{c}$ & $27.4 \mathrm{~b}$ & $5364.3 \mathrm{~b}$ & $2029.8 \mathrm{~b}$ & $8.3 \mathrm{~b}$ \\
\hline 11500 & $253.2 \mathrm{a}$ & $18.9 \mathrm{~d}$ & $30.1 \mathrm{a}$ & $5669.4 \mathrm{a}$ & $2221.2 \mathrm{a}$ & $8.8 \mathrm{a}$ \\
\hline \multicolumn{7}{|c|}{$\begin{array}{l}\text { Ekim Şekli x Bitki Sıklığı } \\
\left(\text { cm * bitki da }^{-1}\right)\end{array}$} \\
\hline $50 * 5500$ & $233.0 \mathrm{fg}$ & 23.2 & 18.1 & 4089.0 & $1071.9 \mathrm{~g}$ & 6.0 \\
\hline $50 * 7500$ & $240.0 \mathrm{de}$ & 21.6 & 24.9 & 4474.8 & $1496.5 \mathrm{ef}$ & 7.5 \\
\hline $50 * 9500$ & $248.0 \mathrm{bc}$ & 19.2 & 26.0 & 5188.1 & $1844.7 \mathrm{~cd}$ & 7.8 \\
\hline $50 * 11500$ & $250.2 \mathrm{~b}$ & 17.8 & 28.5 & 5449.0 & $2173.4 \mathrm{ab}$ & 8.1 \\
\hline $70 * 5500$ & $237.1 \mathrm{ef}$ & 23.2 & 19.4 & 4356.5 & $1309.4 \mathrm{f}$ & 7.0 \\
\hline $70 * 7500$ & $241.6 \mathrm{de}$ & 21.9 & 25.2 & 4815.5 & $1587.6 \mathrm{e}$ & 7.6 \\
\hline $70 * 9500$ & $249.3 \mathrm{~b}$ & 20.6 & 26.6 & 5333.3 & 1997.4 b-d & 8.2 \\
\hline $70 * 11500$ & $251.3 \mathrm{~b}$ & 18.3 & 30.1 & 5563.9 & $2175.0 \mathrm{ab}$ & 8.4 \\
\hline $25+45 * 5500$ & $231.1 \mathrm{~g}$ & 26.1 & 21.2 & 4922.8 & $1810.3 \mathrm{~d}$ & 7.4 \\
\hline $25+45 * 7500$ & $243.1 \mathrm{~cd}$ & 24.1 & 26.0 & 5267.3 & $2009.4 \mathrm{bc}$ & 8.0 \\
\hline $25+45 * 9500$ & $250.3 \mathrm{~b}$ & 22.2 & 29.6 & 5571.5 & $2247.3 \mathrm{a}$ & 8.9 \\
\hline $25+45 * 11500$ & $258.0 \mathrm{a}$ & 20.5 & 31.8 & 5995.5 & $2315.1 \mathrm{a}$ & 9.9 \\
\hline \multicolumn{7}{|l|}{ F test } \\
\hline$Y_{11}$ & $* *$ & $* *$ & $*$ & $*$ & $*$ & $* *$ \\
\hline Ekim Şekli (E) & $*$ & $* *$ & $*$ & $* *$ & $* *$ & $* *$ \\
\hline Bitki Sıklığg (B) & $* *$ & $* *$ & $* *$ & $* *$ & $* *$ & $* *$ \\
\hline ExB & $*$ & öd & öd & öd & $* *$ & öd \\
\hline
\end{tabular}

*, ${ }^{* *}$ : Sirasıyla 0.05 ve 0.01 olasllık düzeylerinde istatistiki olarak önemli. öd: önemsiz

Çalışmamıza ait ham protein oranı sonuçları incelendiğinde, gerek ekim şekilleri gerekse bitki sıklıkları istatistiki olarak önemli etkide bulunmuştur. Farklı yetiştirme koşullarının oluşmasına sebep olan bitki yoğunlukları ve ekim şekilleri ham protein oranında değişime neden olmuştur. $25+45 \mathrm{~cm}$ ekim şeklinde ham protein oranında yüksek değerler belirlenmiştir. $\mathrm{Bu}$ konuda yapılan diğer araştırmalarda farklı sonuçlar ortaya çıkmıştır. İptaş ve Acar (2006) bitki yoğunluklarının ham protein oranını etkilemediğini, JiWang ve ark. (2004) bitki sıklığı artması ile ham protein oranının da önemli ölçüde arttı̆̆ını bildirmiş̧lerdir. Birbirinden farklı sonuçlar çıkması, kullanılan çeşit, agronomik uygulamalar, iklim ve toprak gibi faktörlerin farklı olmasından kaynaklanmış olabilir.

\section{SONUÇ}

Araştırma sonuçlarına göre, $25+45 \mathrm{~cm}$ ekim şekli incelenen özelliklerde en yüksek sonucu verirken, bitki yoğunlukları arttıkça bitki boyu, yaprak oranı, ham protein oranı, yeşil ve kuru ot verimi artmış, sap 
kalınlığg azalmıştır. İki yılın sonuçlarına göre, $25+45 \mathrm{~cm}$ ekim şekli kuru ot veriminde $70 \mathrm{~cm}$ ekim şekline göre $\% 17.5,50 \mathrm{~cm}$ ekim şekline göre ise \%25.7 üstünlük sağlamıştır.

Özet olarak, araştırma sonuçları deneme şartları altında silajlık mısırda kaliteli ve yüksek verim için 11500 bitki da ${ }^{-1}$ yoğunluğu ve $25+45 \mathrm{~cm}$ ekim şeklinde üretiminin yapılabileceğini göstermiştir.

\section{KAYNAKLAR}

Açıkgöz E, Turgut İ ve Filya İ 2002. Silaj Bitkileri Yetiştirme ve Silaj Yapımı. Hasad Yayıncılık Ltd. Şti., $86 \mathrm{~s}$.

Buehring NW, Harrison MP and Dobbs, RR 2003. Corn response to twin and narrow rows with selected seeding rates. Agronomy, Cap.11, p.639-686.

Cox WJ and Cherney DJR 2001. Row Spacing, Plant Density and Nitrogen Effects on Corn Forage. Agron. J. 93:597-602.

Cusicanqui JA and Lauer JG 1999. Plant Density and Hybrid Influence on Corn Forage Yield and Quality. Agronomy Journal 91:911-915.

Dostalek R and Hruska L 1985. Effect of Crop Density on the Production in Maize Seed. Rastlinna Vyroba 31(10) 1103-1110.

Geren H 2000. Ana ve ikinci ürün olarak yetiştirilen silajlık misır (Zea mays L.) çeşitlerinde ekim zamanlarının hasıl verimleri ile silaja ilişkin tarımsal özelliklere etkisi üzerinde araştırmalar, Ege Üniv. Fen Bilimleri Enst. Tarla Bitkileri Anabilim Dalı (Basılmamış Dr.Tezi), 251s.

Gözübenli H, Kılınc M, Sener O and Konuskan O 2004. Effect of single and twin row planting on yield and yield components in maize. Asian Journal of Plant Sciences 3 (2): 203-206.

Heimbeck W, Schwarz FJ and Kirchgessner M 1988. Auswirkungen eines Quetschens von MaisGesamtpflanzen und Maiskörnern auf die Nahrstoffverdaulichkeit. 1. Mitteilung. Das wirtschaftseigene Futter 34 (1)15-16.

İptaş S 1993. Tokat şartlarında birinci ürün silajlık mısır (Zea mays), sorgum (Sorghum vulgare), Sudanotu (Sorghum sudanense) ve SorgumSudanotu melezinin değişik olgunluk devrelerinde yapılan hasatların verim ve silajlık özellikler ile kaliteye etkileri üzerinde araştırmalar, Ege Üniv.Fen Bilimleri Enstitüsü Tarla Bitkileri Anabilim Dalı (Basılmamış Doktora Tezi), Bornova-İzmir, 133s.
İptaş S. and Acar AA 2006. Effects of Hybrid and Row Spacing on Maize Forage Yield and Quality, In Plant: Soil and Environment, 52 (11):515-552.

Jiwang Z, Changhao HO, Kongjun W, Shuting D and Peng L 2004. Effects of Plant Density on Forage Nutritive Value of Whole Plant Corn. Agricultural Sci. in China, 3(11):842-848.

Kızılşimşek M, Erol A ve Kaplan M 2005. Farklı Bitki Sıklıklarının Silajlık Mısır Çeşitlerinde Yaprak Alanı Gelişimi ve Işık Kullanımı Üzerine Etkileri. Türkiye VI. Tarla Bitkileri Kongresi, 59 Eylül 2005. Antalya.(2):1005-1010.

Kolcar F and Videnovic Z 1985. Yield of Some Maize Hybrids Depending on Plant Density and Amounts of Fertilizers. Arhiv za Poljoprivredne Nauke, 44(155): 315-322.

Mcgraft, C 2005. Twin Row Corn Study. Iowa State Univercity, Arm Strong

Olson, RA and Sanders DH 1988. Maize production. In: G.F. Sprague, J.W. Dudley. Corn and corn improvement. Madison: American Society of Agronomy, Cap.11, p.639-686.

Saruhan V ve Şireli D 2005. Misır (Zea mays L.)Bitkisinde Farklı Azot Dozları ve Bitki Sıklığının Koçan,Sap ve Yaprak Verimlerine Etkisi Üzerine Bir Araştırma. Harran Üniv. Ziraat Fakültesi Dergisi, 9(2):45-55.

Shaw RH 1988. Climate Requirement Corn and Corn Improvement. ASA, CSSA, SSSA, 609-638, Wisconsin,USA.

Şener O, Gözübenli H, Konuşkan Ö ve Kılınç M 2004. The Effect of Intra Row Spacings on the Grain Yield and Some Agronomic Characteristics of Maize (Zea mays L.) Hybrids. Asian Journal of Plant Sciences. 3(4):429-432.

Turgut İ, Duman A, Bilgili U ve Açıkgöz E 2005. Alternate Row Spacing and Plant Density Effects on Forage and Dry Matter Yield of Corn Hibrids (Zea mays L.). J. Agronomy\& Crop Science 191, 2005. p.146-151.

Yı1maz S, Gözübenli H, Konuşkan Ö ve Atış İ 2007. Genotype and Plant Density on Corn (Zea mays L.) Forage Yield, Asian Journal of Plant Sciences. 6(3):538-541.

Yılmaz S, Eryaman M, Gözübenli H ve Can E 2008. Twin or Narrow-Row Planting Patterns versus Conventionel Planting in Forage Maize Production in the Eastern Mediterranean. Cereal Research Comminications. Akademi Kiado. V:36, N:1, 189-199 p. 